\title{
CONTAMINATION STUDIES ON MOLLUSK SHELL SAMPLES
}

\author{
TOMASZ GOSLAR and MIECZYSKAW F PAZDUR
}

Radiocarbon Laboratory, Institute of Physics, Silesian Technical University, Krzywoustego 2, PL-44-100 Gliwice, Poland

ABSTRACT. A series of shell samples has been studied to determine the magnitude and mechanisms of carbon exchange between shells and their environment. Laboratory contamination experiments included the storing of shell samples in acid and calcareous environments of different ${ }^{14} \mathrm{C}$ concentrations as well as studies of carbon exchange in the course of thermal recrystallization in solid state in an atomosphere of carbon dioxide. The applicability of differential thermal analysis to studies of the structure and texture of shells is discussed.

\section{INTRODUCTION}

The problem of sample contamination seems to be of special significance in the dating of mollusk shells, as foreign carbon may enter a sample due to the surface exchange between the sample $\mathrm{CaCO}_{3}$ and the environment. Occurring in the same form as the sample material, the contaminant cannot be practically removed by chemical pretreatment. In such a situation one should only try to check if such an exchange has occurred.

The mechanisms of shell carbonate contamination have been discussed by numerous authors (Olsson, 1968, 1974; Craig, 1954; Mangerud, 1972; Thommeret, 1976; Polach, 1976). According to Craig (1954) the only mechanism of isotopic exchange fast enough at temperatures found in nature is the recrystallization of shell carbonate by means of solution and its reprecipitation. In the process of recrystallization, primary aragonite, the main component of shell carbonate of most species, is dissolved, and the reprecipitated carbonate has a calcite structure. Calcite itself, however, could exchange carbon atoms with bicarbonates from its environment (Thommeret, 1976). A small exchange can also occur at the shell surface during long storage in open air (Olsson, 1974).

There are several criteria which may help to detect the contamination of shell carbonate due to carbon exchange. X-ray examination of the mineralogic structure proves that no recrystallization has taken place, except in shells of a primary aragonite structure. In dating marine shells, the possibility of contamination should be accounted for if $\delta^{13} \mathrm{C}<-3 \%$ vs PDB (Mangerud, 1972). An alternative isotopic criterion can be based on $\delta^{18} \mathrm{O}$ values (Craig, 1954). The degree of contamination may also be estimated visually, as stated by some authors, since shells with a good surface texture and wellpreserved periostracum are usually recrystallized less than those with weak surface textures (Taft, 1976; Mangerud, 1972).

The main aim of our work was to determine the magnitude and mechanisms of carbon exchange between shells and their environment in various artifically produced conditions and to check the potential use of differential thermal analysis in studies of post-depositional changes of the structure and composition of shells.

\section{SAMPLE DESCRIPTIONS}

The samples designated ZO-1 to ZO-6 are marine shells of Mya truncata, Hiatella arctica, and Mytilus edulis, collected 1975 on the marine ter- 
races of King Oscar Land, West Spitsbergen by Jan Szupryczyński, Polish Academy of Science, Torun, and dated for studies of the rate of isostatic uplift after the recession of the Billefjorden ice sheet (Boulton, 1979). Samples M79 (Helix pomatia) and M81 (Helix and Cepea sp) were collected by the first author in November 1979 in Będzin and in September 1981 in Opole, respectively. The shells were empty, partly filled with soil and sand and covered with dry leaves. Sample J-1-80 consists of shells of freshwater species Lymnaea, collected 1980 in Jaroszów near Wałbrzych by Henryk Chmal, Geographic Institute, Wrocław University, Wrocław.

\section{CONTAMINATION EXPERIMENTS}

\section{Limestone Environment}

A portion of ca $60 \mathrm{~g}$ of crushed shells of sample M79 was mixed with ca $300 \mathrm{~g}$ of ${ }^{14} \mathrm{C}$-free chalk and ca $200 \mathrm{~g}$ of peat, dated to $>42,500$, Gd-1076, and $>42,900$, Gd-1077 (R, 1983, v 25, p 850) and placed with some water in a tightly closed glass jar. The mixture was stored for 133 days at a temperature of 50 to $60^{\circ} \mathrm{C}$. The same experiment was repeated with the sample M81. The resulting samples were designated as M79wap and M81wap, respectively.

\section{Acid Environment}

A portion of $100 \mathrm{~g}$ of shells of sample ZO-4 was mixed with ca $200 \mathrm{~g}$ of recent active soil with plant fragments and placed with $200 \mathrm{~cm}^{3}$ of diluted citric acid with a $\mathrm{pH}=2.5$ in a tightly closed glass jar and stored for 133 days at $60-50^{\circ} \mathrm{C}$. As the sample ZO-4 was dated to ca $10,500 \mathrm{yr}$ вP (see table 3 ), any exchange of carbon should produce a younger age of the resulting sample, denoted as ZO-4kwas.

\section{Gaseous $\mathrm{CO}_{2}$ Environment at Elevated Temperatures}

For studies of carbon exchange during recrystallization in solid state, shells of the ZO-4 sample were subjected to three experiments:

1) $\mathrm{ZO}-4 \mathrm{~A} / 500$. The shells were heated for 2 hours at a temperature of $450-550^{\circ} \mathrm{C}$ (aragonite-calcite transition) in an atmosphere of carbon dioxide of ${ }^{14} \mathrm{C}$ activity equal to $3300 \mathrm{PM}(\mathrm{PM}=$ per cent of modern).

2) $\mathrm{ZO}-4 / 500$. The shells were heated as above for 8 hours; in the last 15 minutes the temperature was raised to $950^{\circ} \mathrm{C}$ and the apparatus was open to air.

3) ZO-4/900. The shells were heated for 2 hours at a temperature of $800-900^{\circ} \mathrm{C}$ in an atmosphere of $\mathrm{CO}_{2}$ of ${ }^{14} \mathrm{C}$ activity equal to $187 \pm 11 \mathrm{PM}$. In the last two experiments a small amount of air was present in the $\mathrm{CO}_{2}$ atmosphere.

\section{X-RAY ANALYSES}

Table 1 presents the results of the mineralogic x-ray analysis of shell samples. Some samples were subjected to additional measurements in order to estimate the size of the crystalline grains. Most of the studied samples have an aragonite structure. Shells of Mya truncata show also traces of 


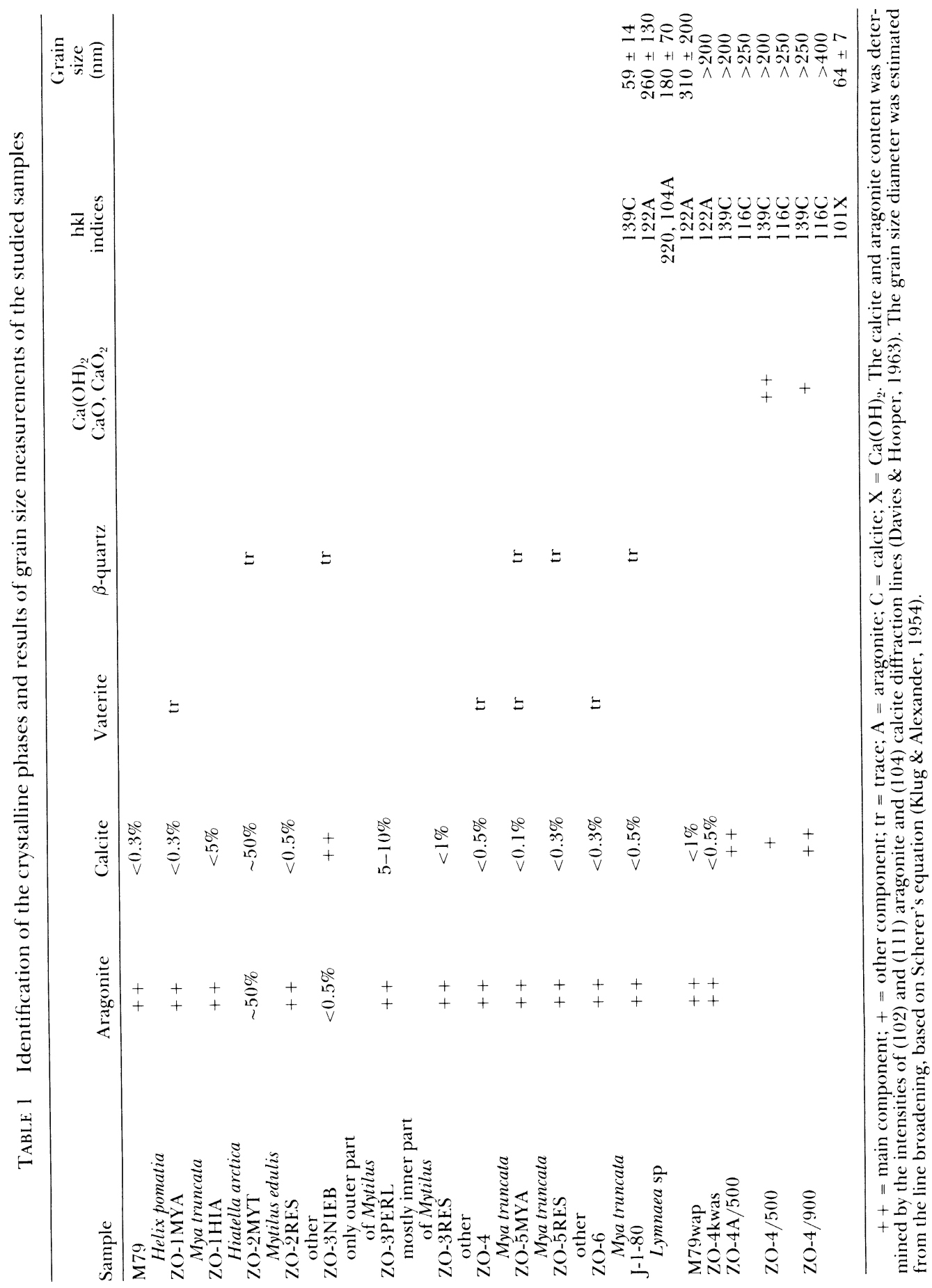


vaterite, which is not found in other shells. The $\beta$-quartz lines probably result from minute amounts of sand on the surface of some shells. The samples ZO-2MYT, ZO-3NIEB, and ZO-3PERL consist of species producing a blue calcite layer and pearly aragonite layer (Keith, Anderson, \& Eichler, 1964; Thommeret, 1976), so the presence of calcite diffraction lines does not prove their recrystallization. The higher calcite content in the ZO1HIA sample may have been connected with the fact that the surface of the shells was soft and "loose." No correlation was found between the degree of recrystallization and the amount of conchioline.

Samples subjected to elevated temperatures were totally recrystallized. The presence of $\mathrm{CaO}, \mathrm{CaO}_{2}$, and $\mathrm{Ca}(\mathrm{OH})_{2}$ in samples $\mathrm{ZO}-4 / 500$ and $\mathrm{ZO}-$ $4 / 900$ is caused by a partial decomposition of calcite and the subsequent adsorption of water vapor and oxygen from air.

The size of the crystalline grains is of the order $10^{2}-10^{3} \mathrm{~nm}$. The smaller size of calcite grains observed in sample J-1-80 might suggest that this calcite was formed by dissolution and reprecipitation. We did not find out for certain, however, if the size of the crystalline grains changes during the thermally induced transition of aragonite into calcite. The answer to the question whether measurements of the grain size might help to determine the primary or secondary origion of the calcite present in some shells needs additional precise measurements.

\section{THERMAL ANALYSES}

Thermal analyses of shells were carried out to estimate their chemical composition and crystalline structure and, if possible, the packing of their polycrystalline texture. During the thermal analysis, an investigated sample and appropriate standard reference sample, placed in two pots, are heated at a constant rate, and the temperature of the reference sample together with the difference of temperatures between the reference and investigated samples are plotted as functions of time (curves T and DTA, respectively, fig 1). In an ideal case, curve T should be a straight line. Any endothermic or exothermic transformation of the sample is revealed by a corresponding minimum or maximum of the DTA curve, and, if the reaction heat is sufficiently high, a deviation of curve $\mathrm{T}$ from linearity could also be observed. Curve TG (fig 1) records the loss of sample mass in the function of time.

The DTA curve of calcite has one minimum corresponding to its decomposition: $\mathrm{CaCO}_{3} \rightarrow \mathrm{CaO}+\mathrm{CO}_{2} \uparrow$, at temperatures of $920-950^{\circ} \mathrm{C}$ (Liptay, 1971). Aragonite should give, on the DTA curve, an additional small endothermic peak at $470-480^{\circ} \mathrm{C}$, corresponding to the aragonite-calcite transition. TG curves are identical for both structures (Liptay, 1971). The equilibrium temperature of the decomposition of $\mathrm{CaCO}_{3}$ in air is equal to $787^{\circ} \mathrm{C}$ (Schultze, 1974). The real equilibrium temperature increases, however, with the increase of the local $\mathrm{CO}_{2}$ pressure in the pores between the individual grains. Moreover, since the reaction rate at the boundary solid-gaseous phase is limited, decomposition of calcite occurs at higher temperatures. Both effects cause a broadening and shifting of the DTA peaks of calcite decomposition.

The parameters of the TG and DTA curves of the investigated shell 


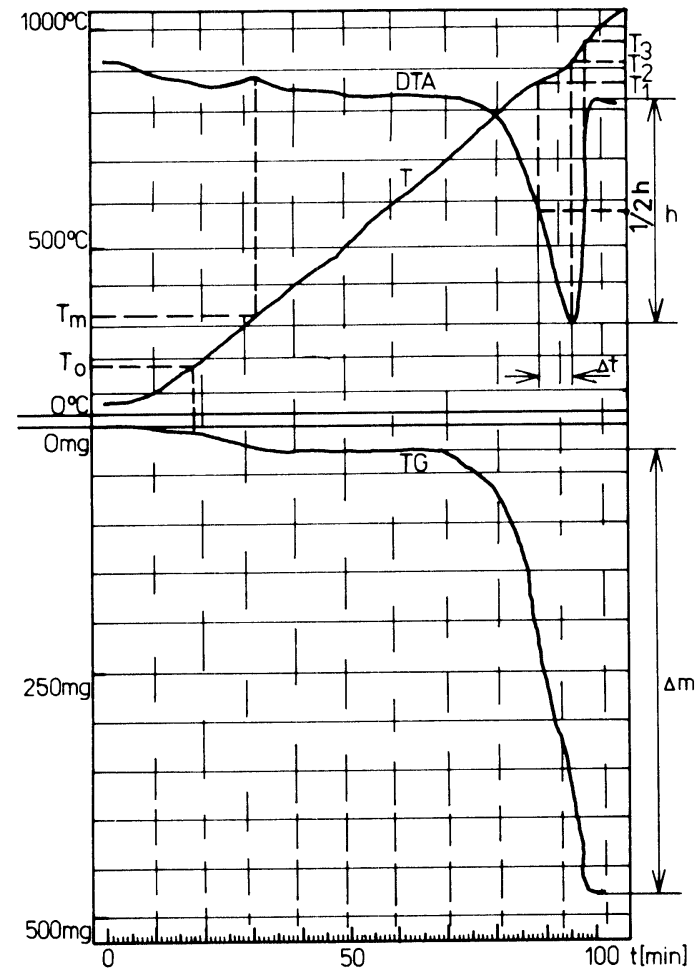

Fig 1. An example of differential thermal analysis curves (sample ZO-3RES) with indicated parameters of the DTA and TG curves.

samples are listed in table 2. No peak of aragonite-calcite transition was observed in any of the studied samples, even at an increased sensitivity of the DTA curve. All samples show a small decrease of mass below $100^{\circ} \mathrm{C}$, interpreted as dehydration. The loss of mass in the temperature interval from $100^{\circ} \mathrm{C}$ to $\mathrm{T}_{o}$, and small exothermic peak of the DTA curve at $\mathrm{T}_{\mathrm{m}}$ correspond to the burning of organic matter of the shell. The values of $\mathrm{T}_{o}$ and $\mathrm{T}_{\mathrm{m}}$ are presented graphically in figure 2. The character of both of these diagrams scems to indicate that organic matter is variously distributed in shells of different species. The lack of a $T_{m}$ peak in three samples is to be attributed to the low content of organic fractions in these shells. Thermal analyses show that organic fraction does not occur in shells subjected to elevated temperatures. Instead, these samples show an endothermic peak and corresponding loss of mass due to the decomposition of $\mathrm{Ca}(\mathrm{OH})_{2}: \mathrm{Ca}(\mathrm{OH})_{2} \rightarrow$ $\mathrm{CaO}+\mathrm{H}_{2} \mathrm{O} \uparrow$ (Liptay, 1975).

The diagrams in figure 3 show the localization of the DTA peak of calcite decomposition and its width, both in time and temperature scales. Two groups of samples were distinguished, separated in table 2 by a broken line. The Student test at the significance level $\alpha=0.001$ indicates that only the difference of the mean values of $\Delta t$ for both groups is significant. Such 
TABLE 2

Parameters of the TG and DTA curves of the studied samples

\begin{tabular}{|c|c|c|c|c|c|c|c|c|}
\hline Sample & $\mathrm{m} \mathrm{mg}$ & $\mathrm{p} \%$ & $\mathrm{~T}_{0}$ & $\mathrm{~T}_{\mathrm{m}}$ & $\mathrm{T}_{2}$ & $\mathrm{~T}_{2}-\mathrm{T}_{1}$ & $\mathrm{~T}_{3}-\mathrm{T}_{2}$ & $\Delta \mathrm{t}$ \\
\hline ZO-1MYA & 1100 & 95.5 & 200 & 320 & 920 & 45 & 40 & 1.4 \\
\hline ZO-1 HIA & 1100 & 95.6 & 200 & 320 & 910 & 50 & 40 & 1.4 \\
\hline ZO-2MYT & 1100 & 96.5 & 270 & 330 & 920 & 55 & 40 & 1.4 \\
\hline $\mathrm{ZO}-2 \mathrm{RES}$ & 1100 & 95.9 & 200 & 320 & 900 & 50 & 40 & 1.5 \\
\hline ZO-3NIEB & 1100 & 94.5 & 300 & 340 & 920 & 35 & 40 & 1.25 \\
\hline ZO-3PERL & 1100 & 94.8 & 240 & 320 & 915 & 40 & 40 & 1.3 \\
\hline ZO-3RES & 1100 & 95.5 & 200 & 320 & 920 & 50 & 40 & 1.4 \\
\hline $\mathrm{ZO}-4$ & 1100 & 95.9 & 200 & 320 & - & - & - & - \\
\hline ZO-5MYA & 1100 & 95.6 & 190 & 320 & 925 & 40 & 35 & 1.3 \\
\hline ZO-5RES & 1300 & - & 180 & 320 & 930 & 40 & 40 & 1.3 \\
\hline ZO-6 & 1300 & - & 180 & 320 & 920 & 40 & 40 & 1.4 \\
\hline$J-1-80$ & 1100 & 93.8 & 200 & $\mathrm{n}$ & 905 & 40 & 40 & 1.3 \\
\hline M79wap & 1100 & 97.1 & 430 & $\mathrm{n}$ & 935 & 30 & 35 & 1.0 \\
\hline M79wap* & 820 & 97.3 & 420 & $\mathrm{n}$ & 925 & 30 & 35 & 1.1 \\
\hline $\mathrm{ZO}-4 *$ & 1100 & 95.9 & 200 & 320 & 930 & 25 & 35 & 0.95 \\
\hline $\mathrm{ZO}-4 \mathrm{kwas}$ & 1100 & 94.6 & 200 & 320 & 925 & 30 & 30 & 1.0 \\
\hline $\mathrm{ZO}-4 \mathrm{~A} / 500$ & 1100 & 96.3 & $\mathrm{n}$ & $\mathrm{n}$ & 930 & 30 & 35 & 1.1 \\
\hline $\mathrm{ZO}-4 / 500$ & 1000 & 56.4 & 374 & 58 & 865 & 30 & 25 & 0.9 \\
\hline $\mathrm{ZO}-4 / 900$ & 1100 & 78.9 & 119 & 111 & 920 & 35 & 30 & 0.9 \\
\hline & $\begin{array}{c}\text { mass of } \\
\text { mg }\end{array}$ & & $\mathrm{Ca}(\mathrm{OH})_{2}$ & \multicolumn{2}{|c|}{$\mathrm{CaO}, \mathrm{CaO}_{2}$} & & & \\
\hline
\end{tabular}

Parameters: heating rate $-11^{\circ} \mathrm{C} / \mathrm{min}$, ITA sensitivity $-1 / 20$, TG sensitivity -500 , $*=$ DTA sensitivity $-1 / 10 ; \mathrm{m}=$ mass of the sample; $\mathrm{p}=\mathrm{CaCO}_{3}$ content in $\% ; \mathrm{n}=$ no peak

results suggest that the supposed differences in the composition of calcite are connected more likely with the reaction rate at the boundary solid-gaseous phase than with the increase of the local $\mathrm{CO}_{2}$ pressure. Crystalline grains are probably greater in samples of the first group.

\section{${ }^{14} \mathrm{C}$ AND ${ }^{13} \mathrm{C}$ MEASUREMENTS}

Table 3 shows the results of measurements of ${ }^{14} \mathrm{C}$ and ${ }^{13} \mathrm{C}$ for samples used in studies of carbon exchange. ${ }^{14} \mathrm{C}$ dates of other shell samples will be published elsewhere (Goslar \& Pazdur, 1984) The $\delta^{13} \mathrm{C}$ values of Spitsbergen shells lie in the range from +0.9 to $+2.6 \%$ vs PDB, for the freshwater sample, J-1-80, $\delta^{13} \mathrm{C}=-6.38 \pm 0.04 \%$ vs $\mathrm{PDB}$, as was to be expected.

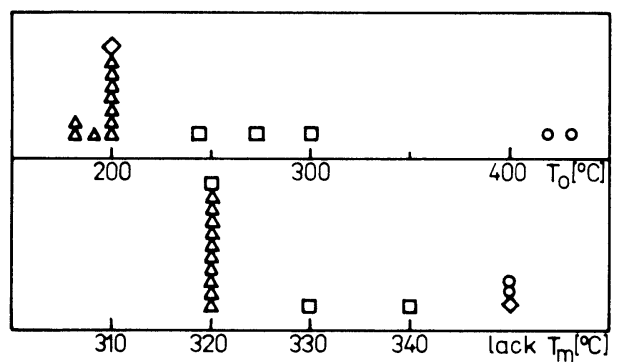

Fig 2. Temperatures of the beginning $\left(\mathrm{T}_{\mathrm{o}}\right)$ and the maximum $\left(\mathrm{T}_{\mathrm{m}}\right)$ of the burning of shell organic matter. $\Delta=$ Mya, Hiatella; $\square=$ Mytilus; $\mathrm{O}=$ Helix; $\diamond=$ Lymnaea. 


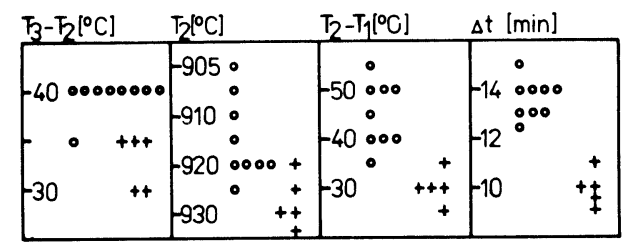

Fig 3. Location and width of the DTA peak of the decomposition of calcite.

DISCUSSION OF THE CONTAMINATION EXPERIMENTS

\section{Limestone Environment}

The difference of ${ }^{14} \mathrm{C}$ activity of $\mathrm{M} 79$ and M79wap samples is great, which is quite surprising because both samples are of an aragonite structure. The experiment has been repeated on sample $M 81$, and no significant change of ${ }^{14} \mathrm{C}$ activity was found. Also, measurements of $\delta^{13} \mathrm{C}$ do not suggest any significant exchange. As the only explanation of this controversy we suggest a temporal inhomogeneity of sample M79, caused by the incorporation of a few shells a dozen or so years older (see fig 4 ).

\section{Acid Environment}

The results of ${ }^{14} \mathrm{C}$ activity measurements in samples $\mathrm{ZO}-4$ and $\mathrm{ZO}-$ $4 \mathrm{kwas}$ give no evidence of carbon exchange in the external part of the shell sample. Exchange degree denotes the fraction of total carbon which is exchanged with those from the surrounding environment causing measured shift of ${ }^{14} \mathrm{C}$ activity without any change of sample mass. Assuming the contamination of the external part of the $\mathrm{ZO}-4 \mathrm{kwas}$ sample with recent soil organic matter of ${ }^{14} \mathrm{C}$ activity equal to $150 \pm 20 \mathrm{PM}$, the estimated exchange degree would be $9 \pm 7 \%$. Such a small exchange may have taken place during the dissolution of aragonite and the subsequent reprecipitation of calcite. This hypothesis seems to be confirmed by the lower content of $\mathrm{CaCO}_{3}$ in the sample $\mathrm{ZO}-4 \mathrm{kwas}$ and the small shift of the $\delta^{13} \mathrm{C}$ value. As the above small admixture of calcite lies below detection limit of X-ray anal-

TABLE 3

Results of ${ }^{13} \mathrm{C}$ and ${ }^{14} \mathrm{C}$ measurements of the shells used in exchange experiments

\begin{tabular}{lccc}
\hline Sample & $\delta^{13} \mathrm{C} \%$ vs PDB & ${ }^{14} \mathrm{C}$ activity $(\mathrm{PM})$ & Age BP or $\Delta^{14} \mathrm{C}$ \\
\hline ZO-4 OUT & $+1.81 \pm 0.15$ & $27.28 \pm 0.28$ & $10,430 \pm 90$ \\
ZO-4IN & same & $26.95 \pm 0.48$ & $10,530 \pm 150$ \\
ZO-4kwasOUT & $+2.46 \pm 0.16$ & $28.24 \pm 0.32$ & $10,160 \pm 90$ \\
ZO-4kwasIN & same & $26.28 \pm 0.50$ & $10,730 \pm 160$ \\
M79 & $-10.84 \pm 0.11$ & $144.51 \pm 1.10$ & $445 \pm 11$ \\
M79wapOUT & $-10.91 \pm 0.11$ & $135.90 \pm 1.53$ & $359 \pm 16$ \\
M79wapIN & same & $135.45 \pm 0.74$ & $355 \pm 8$ \\
M81OUT & $-10.40 \pm 0.03$ & $134.48 \pm 0.95$ & $345 \pm 10$ \\
M81IN & same & $135.87 \pm 0.65$ & $359 \pm 7$ \\
M81wapOUT & $-10.89 \pm 0.04$ & $134.34 \pm 1.08$ & $343 \pm 11$ \\
M81wapIN & $-10.74 \pm 0.08$ & $134.65 \pm 1.04$ & $347 \pm 11$ \\
ZO-4A/500 & $+1.80 \pm 0.05$ & $28.51 \pm 0.29$ & $10,080 \pm 90$ \\
Z(O-4/500 & $-4.58 \pm 0.08$ & $45.78 \pm 0.63$ & $6280 \pm 120$ \\
ZO-4/900 & $-1.41 \pm 0.14$ & $34.93 \pm 0.45$ & $8450 \pm 110$ \\
\hline
\end{tabular}




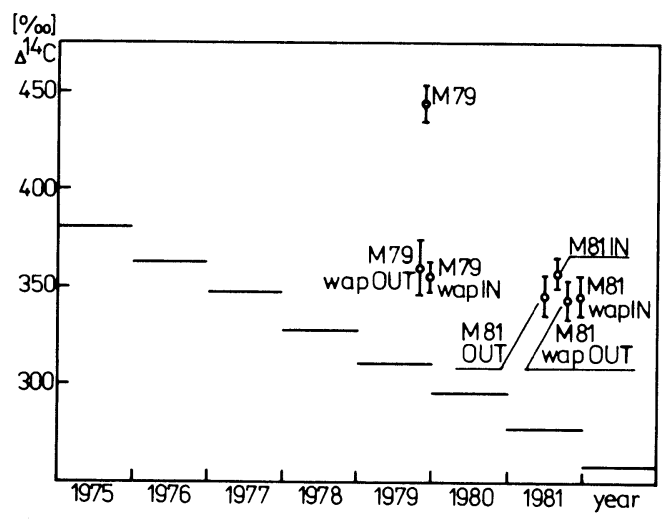

Fig 4. Results of ${ }^{14} \mathrm{C}$ measurements of shells used in studies of carbon exchange in a calcareous environment. The horizontal bars denote the average annual levels of atmospheric ${ }^{14} \mathrm{C}$ activity estimated from data provided by Levin, Münnich, and Weiss (1980) and Segl et al (1983).

ysis, it is to be concluded that even a recrystallization undetectable by $\mathrm{x}$-ray analysis may cause a significant error of the ${ }^{14} \mathrm{C}$ age of the shell (in the case of sample ZO-4 > $200 \mathrm{yr}$ ).

\section{Elevated Temperatures}

The ${ }^{14} \mathrm{C}$ activity of sample $\mathrm{ZO}-4 \mathrm{~A} / 500$ is ca $1 \%$ higher than that of sample $\mathrm{ZO}-4$. This is equivalent to an exchange degree equal to $0.46 \pm 0.24 \%$. We suppose, however, that this change of ${ }^{14} \mathrm{C}$ activity is not caused by carbon exchange during recrystallization, but by small adsorption of active $\mathrm{CO}_{2}$ in the shell pores. The changes of ${ }^{14} \mathrm{C}$ activity of the $\mathrm{ZO}-4 / 500$ and $\mathrm{ZO}-4 / 900$ samples with respect to the initial sample ZO-4 are equivalent to exchange degrees equal to $5.8 \pm 0.6 \%$ and $50.7 \pm 9.2 \%$, respectively. The assumed mechanism of this exchange comprises the decomposition of $\mathrm{CaCO}_{3}$ and recrystallization, according to the model shown in figure 5 . This model accounts for the burning of organic matter in the shell, the evolving of some $\mathrm{CO}_{2}$, and the adsorption of $\mathrm{H}_{2} \mathrm{O}$ and ${ }^{*} \mathrm{CO}_{2}$ of high ${ }^{14} \mathrm{C}$ concentration by $\mathrm{CaO}$. For the sake of simplicity, the presence of $\mathrm{CaO}_{2}$ is neglected, which is justified by its small amount estimated from the DTA and TG curves. In order to test if such a model describes correctly the complexity of the reactions involved, the values of the coefficient

$$
\alpha=\frac{\left({ }^{13} \mathrm{C} /{ }^{12} \mathrm{C}\right) \mathrm{CO}_{2}}{\left({ }^{13} \mathrm{C} /{ }^{2} \mathrm{C}\right) \mathrm{CaCO}_{3}}
$$

were calculated based on the data obtained in experiments with samples $\mathrm{ZO}-4 / 500$ and $\mathrm{ZO}-4 / 900$. The masses of the individual components were calculated from known amounts of $\mathrm{CaCO}_{3}, \mathrm{CaO}$, and $\mathrm{Ca}(\mathrm{OH})_{2}$ and the known exchange degree of ${ }^{14} \mathrm{C}$ in both experiments. The values of $\delta^{13} \mathrm{C}$ of initial $\mathrm{CO}_{2}$ surrounding the samples were assumed to be $\delta_{1}=-20 \pm 20 \%$ and $\delta_{2}=-22 \pm 5 \%$, respectively. The calculated values of $\alpha$ are equal to $\alpha_{1}=1.0059 \pm 0.0008$ and $\alpha_{2}=1.0052 \pm 0.0023$. The good agreement of 


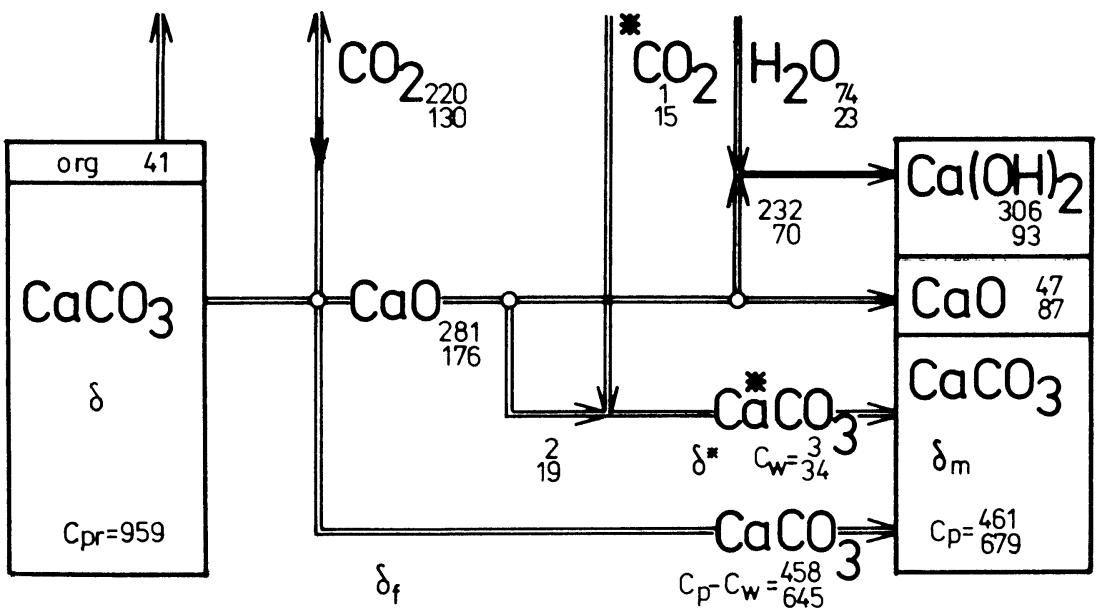

Fig 5. Simplified model of reactions during the heating of shells in a carbon dioxide atmosphere of high ${ }^{14} \mathrm{C}$ activity. $\mathrm{C}_{\mathrm{pr}}=$ initial mass of $\mathrm{CaCO}_{3} ; \mathrm{C}_{\mathrm{w}}=$ mass of $\mathrm{CaCO}_{3}$ formed with external ${ }^{* \mathrm{CO}_{2}} ; \mathrm{C}_{\mathrm{p}}=$ final mass of $\mathrm{CaCO}_{3} ; * \mathrm{C}=$ carbon of high ${ }^{14} \mathrm{C}$ activity; $\delta, \delta^{*}, \delta_{\mathrm{f}}$, and $\delta_{\mathrm{m}}=$ $\delta^{13} \mathrm{C}$ coefficients of the initial sample, external $\mathrm{CO}_{2}, \mathrm{CaCO}_{3}$ after the decomposition of some initial carbonate, and final $\mathrm{CaCO}_{3}$, respectively. The upper and lower numbers denote values from the 1 st and 2 nd experiment (see text).

both these values seems to confirm the suitability of the model presented in figure 5 , despite relatively large errors caused by low accuracy of the assumed values of $\delta$.

\section{CONCLUSIONS}

The results of differential thermal analyses of shell samples indicate that this technique is unsuitable for determining the crystalline structure of shells. Exchange experiments in an acid environment show, however, that even the results of x-ray analysis cannot completely exclude the recrystallization of shells by dissolution and reprecipitation. No carbon exchange was found in experiments with limestone environment and during thermal recrystallization in solid state. A significant isotopic fractionation was proved during the thermal decomposition of calicte. X-ray analysis shows traces of vaterite in shells of Mya truncata. The dimensions of crystalline grains of mollusk shells were determined to be equal to $10^{2}-10^{3} \mathrm{~nm}$. The question based on the measurements of the grain size, of the possibility of distinguishing between primary and secondary calcite remains, as yet, open.

\section{REFERENCFS}

Boulton, G S, 1979, Glacial history of the Spitsbergen archipelago and the problem of a Barents Shelf ice sheet: Boreas, v 8, p 31-57.

Craig, Harmon, 1954, Carbon-13 in plants and the relationship between carbon-13 and carbon-14 variations in nature: Jour Geol, v 62, p 115-149.

Davies, $T$ T and Hooper, P R, 1963, The determination of calcite:aragonite ratio in mollusc shells by X-ray diffraction: Mineralog Magazine, v 33, p 608-612.

Goslar, Tomasz and Pazdur, M F, in press, Datowanie muszli metoda ${ }^{14} \mathrm{C}$ : Kwartalnik Geol, v 28 , in press.

Keith, M L, Anderson, G H, and Eichler, R, 1964, Carbon and oxygen isotopic composition of 
mollusc shells from marine and freshwater environments: Geochim et Cosmochim Acta, $v$ 128 , p $1757-1786$.

Klug, H P and Alexander, L E, 1954, X-ray diffraction procedures for polycrystalline and amorphous materials: New York, John Wiley and Sons, Inc, p 491-537.

Levin, Ingeborg, Münnich, K O, and Weiss, Wolfgang, 1980, The effect of anthropogenic $\mathrm{CO}_{2}$ and ${ }^{14} \mathrm{C}$ sources on the distribution of ${ }^{14} \mathrm{C}$ in the atmosphere, in Stuiver, Minze and Kra, Renee, eds, Internatl radiocarbon conf, 10th, Proc: Radiocarbon, v 22, no.2, p 379 391 .

Liptay, G, 1971, Atlas of thermoanalytical curves: Vol 1, Budapest, Akad Kiado.

___ 1975, Atlas of thermoanalytical curves: Vol 5, Budapest, Akad Kiado.

Mangerud, Jan, 1972, Radiocarbon dating of marine shells, including discussion of apparen age of recent shells from Norway: Boreas, v 1, p 143-172.

Olsson, I U, 1968, Modern aspects of radiocarbon dating: Earth Sci Rev, v 4, p 203-218.

1974, Some problems in connection with the evaluation of ${ }^{14} \mathrm{C}$ dates: Geol Fören Stokholm Förh, v 96, p $311-320$.

Polach, H A, 1976, Radiocarbon dating as a research tool in archaeology-hopes and limitations, in Barnard, Noel, ed, Symposium on scientific methods of research in the study of ancient Chinese Bronzes and South East Asian metal and other archaeological artifacts, Proc: Melbourne, Australia, Natl Gallery Victoria, p 255-298.

Pazdur, M F, Awsiuk, Romuald, Bluszcz, Andrzej, Pazdur, Anna, Walanus, Adam, and Zastawny, Andrzej, 1983, Gliwice radiocarbon dates IX: Radiocarbon, v 25, p 843-866.

Schultze, D, 1974, Termiczna analiza różnicowa: Warszawa, Państwowe Wydawnictwo Naukowe

Segl, Monika, Levin, Ingeborg, Schoch-Fischer, Hilla, Münnich, Marianne, Kramer, Bernd, Tschiersch, Jochen, and Münnich, K O, 1983, Anthropogenic ${ }^{14} \mathrm{C}$ variations, in Stuiver, Minze and Kra, Renee, eds, Internatl radiocarbon conf, 11 th, Proc: Radiocarbon, v 25, p $583-592$.

Taft, W H, 1967, Modern carbonate sediments: Developments in sedimentology, v 9A, p 2950 .

Thommeret, Jean, 1976, Difficultes d'interpretation des dates ${ }^{14} \mathrm{C}$ mesurees a partir des coquilles marines, in Labeyrie, Jacques and Lalou, Claude, eds, Union Internatl des Sc Prehistoriques et Protohistoriques, Cong, 9th: Coll I, Datations absolues et analyses isotopiques en prehistorie, methodes et limites: Paris, CNRS, p 160-169. 